\title{
A VISÃO EPISTEMOLÓGICA DE ISABELLE STENGERS
}

\section{THE EPISTEMOLOGICAL VIEW OF ISABELLE STENGERS}

\author{
Neusa Teresinha Massoni ${ }^{1}$, Marco Antonio Moreira ${ }^{2}$ \\ ${ }^{1}$ Professora da UFRGS/Departamento de Física/neusa.massoni@ufrgs.br \\ ${ }^{2}$ Professor Emérito da UFRGS/Departamento de Física/moreira@if.ufrgs.br
}

\begin{abstract}
RESUMO
Este texto busca apresentar uma visão epistemológica contemporânea da ciência. Tradicionalmente, na epistemologia da ciência, destacam-se as conjeturas e refutações de Karl Popper, os programas de pesquisa de Imre Lakatos, os paradigmas de Thomas Kuhn, as populações de conceitos em evolução de Stephen Toulmin, o anarquismo de Paul Feyerabend e outras visões de certos autores sobre a natureza da ciência. Além disso, discute-se muito a questão da relevância ou não de critérios de demarcação entre ciência e não ciência. No entanto, Isabelle Stengers, em sua perspectiva contemporânea, vê a ciência desde uma óptica crítica, política, sociológica, sem defender que a ciência seja singular ou superior em relação a outras áreas de conhecimento, mas reconhecendo que é uma construção humana com características próprias que incluem matizes políticas e sociais. A ciência não é "pura" ou "dura", mas também não é apenas mais uma área de construção do conhecimento humano.
\end{abstract}

Palavras-chave: epistemologia da ciência, visão contemporânea, aspectos políticos e sociais.

\begin{abstract}
This paper attempts to present a contemporary epistemological view of science. Traditionally, the epistemology of Science emphasizes Karl Popper's conjectures and refutations, Imre Lakatos's research programs, Thomas Kuhn's paradigms, Stephen Toulmin's populations of evolving concepts, Paul Feyerabend's anarchism and some other visions of the certain authors about the nature of science. In addition, there is a lot of discussions about the relevance or not of criteria to distinguish between science and non science. However, Isabelle Stengers, in her contemporary perspective, sees science from a critical, political and sociological view, without saying that science is unique and superior regarding other areas of knowledge, but recognizing that it is a human construction with its own features, that include political and social aspects. Science is not "pure" nor "hard", but it is not just another area of human knowledge.
\end{abstract}

Keywords: epistemology of science, contemporary view, political and social aspects.

\section{INTRODUÇÃO}

Isabelle Stengers é belga nascida em 1949, filósofa e historiadora da ciência. É autora de inúmeros trabalhos entre eles um que se notabilizou, A Nova Aliança (1991), foi escrito em conjunto com o ganhador do Prêmio Nobel de Química de 1977, Ilya 


\section{Ensino, Saúde e Ambiente - V8 (2), pp. 111-141, Agosto, 2015}

Prigogine, sobre a teoria do caos, propõe uma nova visão da ciência, da percepção dos fenômenos organizacionais e da relação do cientista com a natureza, sob o paradigma da complexidade. Stengers é graduada em Química, doutora em Filosofia e leciona na Universidade Livre de Bruxelas. Através de sua obra intitulada A invenção das ciências modernas (1995), que este texto introdutório busca sintetizar, Stengers analisa a ciência sob pelo menos duas diferentes perspectivas: 1) de um lado, lança um olhar crítico à ciência moderna mostrando que ela recorre, de forma onipresente, a uma pretensa autoridade - a ciência e seus experts - de forma semelhante à política em suas lutas por poder, buscando se reafirmar, conquistar aliados e garantir autonomia e visibilidade; 2 ) de outro lado, destaca que a moderna ciência é uma construção em certa medida "singular", pois sabe se reinventar, faz uso sistemático e criativo, por exemplo, da matemática computacional, das tecnologias de informação e comunicação, da instrumentação avançada de uma forma tão dinâmica como nenhum outro projeto humano o faz. É nisto que reside sua singularidade.

Stengers inicia sua análise criticando certas visões epistemológicas do início do século passado que buscavam demarcar a ciência de outros saberes e, dessa forma, reinterpreta conceitos como singularidade, acontecimentos, explicação e nos remete à noção de produção de novos espaços, novos acontecimentos, novas explicações, não imutáveis, não universais nem subservientes.

Sua interpretação da natureza da ciência destoa tanto da concepção dos cientistas que, segundo ela, tendem a acreditar na "singularidade" e/ou "superioridade" da ciência como saber legitimado - percebem-na como uma atividade autônoma que se justifica pela racionalidade e objetividade na busca da verdade, quanto da concepção dos sociólogos que com seus estudos culturais passaram a "denunciar" a atividade científica considerando-a tão ligada ao poder, à política, como qualquer outro projeto social - mas eles próprios veem o seu saber sobre as ciências aproximar-se da verdade, ou seja, defendem a Sociologia como uma autêntica ciência, embora não reconheçam essa mesma possibilidade aos cientistas teórico-experimentais, é como ela se refere às chamadas ciências duras.

Alguns epistemólogos do séc. XX (e. g. Thomas Kuhn, Paul Feyerabend, Stephen Toulmin) alertaram que a ciência é permeada de elementos sociológicos, culturais, humanos e não puramente racionais; chamaram a atenção de que na ciência, como em qualquer outra atividade humana, existem questões de poder, prestígio 


\section{Ensino, Saúde e Ambiente - V8 (2), pp. 111-141, Agosto, 2015}

pessoal, lutas por ascensão na carreira ou por recursos para financiar seus projetos, além de crenças pessoais e de grupo. A racionalidade científica não se pauta apenas por ingredientes lógico-racionais. Estes e outros aspectos são retomados por Stengers sob um novo olhar.

Como ela própria defende, sua interpretação assume um caminho diverso: nem o da "veneração", pois ao invés de evidenciar a "singularidade" da ciência busca eliminá-la (PIVA, 2004); nem o da "denúncia” como pretendem as críticas sociológicas. Ela busca uma terceira via, uma perspectiva em que a ideia é acompanhar a constante reinvenção das afirmativas de "singularidade" e autonomia da ciência, de retorsão ${ }^{1}$ e de mobilização.

Discutir e aclarar a noção desses conceitos é o objetivo deste texto que é apenas uma introdução às ideias de Isabelle Stengers, de maneira que para um aprofundamento é indispensável consultar obras originais, algumas referidas ao final.

Stengers toma como ponto de partida certas críticas de alguns estudos que ela classifica como antropológicos (e.g. Michel Callon, Bruno Latour e Steve Woolgar) que se tornaram conhecidos nas décadas finais do séc. XX e que, argumenta ela, investem contra o ideal de uma ciência pura, tinham como objetivo compreender a ciência como um projeto social qualquer, nem mais deslocado das preocupações do mundo, nem mais universal ou racional do que qualquer outro (STENGERS, 1995, p. 11) e colocaram em questão a separação entre a ciência e a sociedade. Segundo ela, esses estudos acabaram por gerar inquietação entre os cientistas, que saíram em defesa da "causa ameaçada" com distintos argumentos: 1) da "retorsão" - como poderiam os sociólogos desqualificar as ciências, se a Sociologia é ela própria uma ciência e, aliás, uma ciência que pretende explicar todas as outras? Escaparia a Sociologia da desqualificação? 2) do realismo - como poderia a ciência ter conseguido feitos como o de enviar homens à Lua se ela não passa de vínculos sociais? Se não é um saber singular? O fato é que, defende ela, esses estudos geraram “desassossego" e inquietação. Uma inquietação em relação a qual os sociólogos próprios se mostraram indiferentes, alerta ela.

\footnotetext{
${ }^{1}$ Retorsão é um conceito que se guia pelo princípio da reciprocidade, ou seja, pode ser entendida como uma ramificação da Lei de Talião: lei do olho por olho, dente por dente. Refere-se ao ato ou atitude por meio da qual alguém que tenha sido ofendido aplica a quem tenha sido seu agressor as mesmas medidas ou os mesmos processos que este empregou ou emprega contra ele. ISSN 1983-7011
} 
Ensino, Saúde e Ambiente - V8 (2), pp. 111-141, Agosto, 2015

\section{DESASSOSSEGO KUHNIANO}

O desassossego foi similar àquele causado por Thomas Kuhn entre os filósofos da ciência quando propôs, na obra A estrutura das revoluções científicas (2003), que o cientista não é "a ilustração gloriosa do espírito crítico e da racionalidade lúcida", mas que "aprende" a tratar dos fenômenos durante a "ciência normal", orientado por um "paradigma", um modelo prático e teórico que se impõe pela força da evidência e define quais as questões legítimas a ser investigadas, quanto o que pode ser considerado como respostas aceitáveis. E mais, para Kuhn a submissão a um paradigma não é um defeito, mas a garantia, em si, do progresso científico. Para Stengers, os filósofos da ciência manifestaram, a princípio, certo descontentamento às ideias kuhnianas, lembraram que seria impossível colocar no mesmo plano algumas ciências ultrapassadas e a moderna ciência, que seria descabido submeter ciência a efeitos da moda, da imitação etc.

Mas, argumenta ela, ao contrário dos filósofos, os cientistas não tiveram a mesma reação, gostaram dos "paradigmas" de Kuhn e até reconheceram neles uma descrição pertinente para as suas atividades. Então, caberia uma pergunta: por que aquilo que escandalizou os filósofos satisfez tanto os cientistas? A resposta de Stengers é que a descrição de Kuhn preserva a autonomia da comunidade científica frente ao ambiente político e social mais amplo; não só preserva a autonomia, como a institui como condição para o exercício de uma ciência fecunda. Não somente deixaremos de pedir explicações ao cientista quanto a sua escolha e suas prioridades de pesquisa, como é justo e normal que não as possa dar (STENGERS, op. cit., p 14).

A visão de Kuhn justificou uma diferenciação radical entre a comunidade científica - criada por sua própria história, dotada de instrumentos para a produção do conhecimento como para a formação de novatos - e o meio social. Se a sociedade deseja se beneficiar dos subprodutos da ciência, então "não deve atacar" a autonomia da comunidade científica que trabalha em obediência a um paradigma, sob pena de interferir nas condições que garantem o progresso científico. Kuhn abriu, dessa maneira, pondera ela, a esteira que propiciou os estudos sociológicos que tanto escandalizaram muitos cientistas.

Mas Kuhn se fiava na racionalidade dos cientistas para avaliar a fecundidade e o poder dos paradigmas, e sempre que um novo paradigma se estabelecesse (por conta de uma "revolução científica"), ele garantiria a autonomia das comunidades científicas e estas se limitariam a interpretar de uma nova maneira aquilo que caracteriza o ideal de 


\section{Ensino, Saúde e Ambiente - V8 (2), pp. 111-141, Agosto, 2015}

uma "verdadeira" ciência, o progresso cumulativo, a possibilidade de consenso, a irreversibilidade da distinção entre o passado obsoleto e o futuro inédito (ibid., p. 17).

Os estudos sociológicos, por sua vez, desconfiaram dessa racionalidade e em função de um princípio que foi chamado de "princípio da simetria" argumentam que é preciso tornar explícito também o conjunto de fatores "não científicos" envolvidos nesse processo. Seria preciso ficar atentos aos desvios, ou defeitos, em relação ao ideal científico: relações de força, jogos de poder, diferenças de prestígio e de capacidade de captação de recursos entre laboratórios concorrentes, possibilidades de alianças com interesses "impuros", ideológicos, industriais, estatais etc. que são aspectos intrinsecamente sociais.

Para Stengers, a imagem kuhniana da ciência pressupõe se ater à racionalidade científica assumindo-a como a única via capaz de avaliar uma pesquisa num terreno que é o seu, sem ter que prestar contas de seus critérios de avaliação. Isto é, constrói-se uma "história" por meios irracionais (trabalho dos epistemólogos) que se adéqua o mais possível ao que se espera de um trabalho de cunho racional (trabalho dos cientistas). Nesse ponto, a Sociologia buscou impor uma nova imagem à ciência evidenciando a nossa incapacidade de julgar a história de que somos herdeiros. Mas Stengers se questiona: nos "quatro séculos europeus" em que se erigiu a moderna ciência, período, aliás, em que muitas outras inovações singulares aconteceram, indústria, Estado, exército, comércio, estes só teriam entrado na história das comunidades científicas com o duplo papel de fornecer fontes de financiamento e de se beneficiar de seus subprodutos úteis?

\section{CRÍTICAS SOCIOLÓGICAS E RADICAIS}

Existem, aponta Stengers, do ponto de vista sociológico, aspectos "externos" à ciência que colocam o cientista não como produto de uma época e de uma história social, técnica, econômica e política, mas como agente ativo que tira partido dos recursos desse ambiente (ambiente, aliás, que lhe oferece, sem intervir, os meios de existir e trabalhar) para fazer prevalecer suas teses e "esconder" suas estratégias sob a máscara da objetividade (ibid., p.18). É nesse sentido que ela fala em "capacidade de mobilização" da ciência.

Para ela, os sociólogos desejam interpretar as práticas das ciências com princípios diferentes daqueles que os próprios cientistas têm de sua prática. Mas 


\section{Ensino, Saúde e Ambiente - V8 (2), pp. 111-141, Agosto, 2015}

pretendem apenas cumprir seu ofício: seus estudos e críticas recaem sobre a ciência como sobre qualquer outro grupo social/profissional, de maneira que os cientistas não deveriam se sentir escandalizados. E se estão, adverte ela, é porque denunciam a si próprios. Um dos objetivos de Stengers é aclarar e compreender por que os cientistas se sentem escandalizados com às interpretações sociológicas. Voltaremos a esta questão.

Além disso, propõe ela, existem outros grupos que criticam as práticas científicas de uma maneira bem mais contundente do que os sociólogos relativistas²: é o caso das "críticas radicais" à ciência, como a da tecnociência e a das "feministas":

A crítica das "tecnociências" identifica a "racionalidade científica" com uma racionalidade puramente operatória, que reduz ao cálculo e ao domínio técnico o que ela conquistou. Nega toda possibilidade de se distinguir entre produções científicas, técnicas, tecnológicas, e se refere tanto aos dispositivos sócio-técnicos que efetivamente transformam as práticas humanas, como a informática, quanto às "visões científicas de mundo", que reduzem, por exemplo, a realidade a uma troca de informações. (...). A crítica feminista radical parte do mesmo tipo de descrição, porém identifica esta racionalidade, não à destruição de todo valor, mas ao triunfo dos valores "masculinos" (ibid., p.20).

Nos dois casos, tecnocientífico e feminista, quer a racionalidade científica seja vista como um conjunto "dotado" de dinâmica própria ou expresse um modo sexuado de relação com o mundo e com os outros, ela tem o poder de definir seus atores e não pode ser limitada, regulada ou transformada a partir do seu "exterior". Assim, se a "crítica radical” deseja uma "outra ciência" - uma Física ou Química feminina ou uma nova consciência ética para contrapor à tecnocientífica - o ônus da prova recai sobre as mulheres ou sobre as instituições da sociedade que representam esses novos valores. Dessa forma, enquanto a crítica sociológica parece colidir com a concepção dos cientistas, a "crítica radical" busca estabilizar tais concepções, dado que nem a tecnociência nem as feministas querem fazer parecer que o cientista seja um estrategista indiferente à verdade ou interessado em se aliar a poderes que o ajudam a fazer a diferença (capitalismo, rentabilidade, Estado), pois eles próprios praticam essa mesma ciência, defende Stengers.

\footnotetext{
${ }^{2}$ A sociologia relativista pressupõe que cada cultura se expressa de forma diferente e que a atividade humana individual deve ser interpretada no contexto de sua própria cultura. Esse princípio foi estabelecido como axioma na pesquisa de Franz Boas, nas primeiras décadas do século XX e, mais tarde, popularizado pelos seus alunos. Porém, o relativismo não é mero axioma (algo que não precisa ser provado ou um ponto de partida $a$ priori), ao contrário, parte das conclusões que são produzidas da observação e da convivência com outros grupos e com suas convicções. Um dos alunos de Franz Boas, Melville Herskovits, afirmou: "o relativismo cultural decorre de um vasto conjunto de fatos, obtidos ao se aplicar nos estudos etnológicos as técnicas que nos permitiram penetrar no sistema de valores subjacentes às diferentes sociedades". Fonte http://pt.wikipedia.org/wiki/Relativismo_cultural. Acesso: $28 / 01 / 14$.

3 A "crítica radical" e a "feminista", segundo Lincoln et al. (apud Creswell, 2014), pressupõem que a realidade é baseada nas lutas de poder e pela identidade e que essa realidade pode ser conhecida por meio de estudos das estruturas sociais, liberdade, opressão, poder e controle. Em geral, esses grupos valorizam a diversidade de valores nas comunidades, científicas ou sociais. ISSN 1983-7011
} 


\section{Ensino, Saúde e Ambiente - V8 (2), pp. 111-141, Agosto, 2015}

As "críticas radicais" acabam, então, por estabilizar uma ciência em que seus praticantes, comenta ela, não se importarão em participar de comissões de ética ${ }^{4}$ onde apresentarão os "fins da ciência" frente aos "fins da humanidade" e acabarão sendo respeitados como intérpretes privilegiados "do que pode sua ciência" e terão, ao final, suas pretensões atendidas, seja qual for a distância entre essas pretensões e as práticas que as autorizam.

É de destacar que Stengers afirma assumir um riso de humor em relação às "comissões de ética": Eu não quero sentar-me numa "comissão de ética" ao lado de um teólogo, de um psicanalista, de um filósofo especialista em tecnociência e de um médico mandarim douto e moralizador. Quero tornar-me capaz - e estimular outras pessoas a tornarem-se capazes - de intervir nessa história (...) (ibid., p. 28). Não que essas comissões não devam existir, ou que a ciência deva voltar a ser discutida nos salões de eventos sociais sofisticados como no séc. XVIII, mas ela defende que é preciso reinterpretar aquilo que se discute nos comitês de ética, que são, argumenta, burocracias autorizadas pela ciência de grupos que têm a vocação de impor seus "valores", "imperativos" e "visões de mundo" - a expressão de poder que quando se torna argumento de autoridade, se dissimula atrás da objetividade e da racionalidade. Nesse sentido, o "riso de humor" não significa troça, desprezo ou ironia, mas um ideal de apreciar, de acompanhar sem esperar salvação; de recusar sem se deixar aterrorizar.

Retomando sua crítica, Stengers entende que o contraste entre o quadro descrito pela prática científica dos sociólogos relativistas e a das "críticas radicais" é que estes últimos não se preocupam em fazer funcionar o "princípio da simetria" entre vencedores e vencidos (a ciência ocidental que herdamos é aquela dos vencedores), mas, ao contrário, tendem a sancionar os avanços científicos em nome do progresso porque aceitam o critério do "isto funciona" em detrimento da cultura, de seus valores, de seus significados (ibid., p. 22), que são deixados de lado.

\footnotetext{
4 Comissões de ética são órgãos independentes e transdisciplinares que analisam e emitem pareceres sobre aspectos éticos suscitados pelo avanço científico e que envolvam pessoas, animais ou material biológico de origem humana ou animal, no domínio das ciências. O objetivo alegado é garantir respeito pela dignidade e identidade e assegurar a tutela dos direitos e liberdades fundamentais dos seres vivos. Surgiram sob o argumento de que o extraordinário avanço científico das últimas décadas acabou atingindo o ser humano e os animais e de que haveria a necessidade de balizamento ético para as pesquisas envolvendo-os, visando coibir deslizes éticos (e. g. experimentos abusivos cometidos nos campos de concentração na Segunda Guerra Mundial, que deu origem ao Código de Nuremberg, 1947 - primeiro documento internacional específico para a pesquisa em seres humanos, criado para julgar os "crimes contra a humanidade"); na sequência, veio a Declaração Universal de Direitos dos Animais (Unesco, 1978), ambos em nível internacional; no Brasil, iniciou com a Resolução 196/96 do Conselho Nacional da Saúde e com o desenvolvimento de agências de regulação (FDA, Emae, Anvisa), visando regular o uso de "animais de experimentação". A partir dos anos 90, a ética na pesquisa resultou na criação de agências de regulação, além da Resolução 196/96, que culminou com a criação dos "comitês de ética de pesquisa (CEP)" para avaliar os projetos de pesquisa em humanos e em animais, às vezes com critérios muito similares. ISSN 1983-7011
} 


\section{Ensino, Saúde e Ambiente - V8 (2), pp. 111-141, Agosto, 2015}

Essa diferença é tomada por Stengers como uma primeira abordagem da singularidade das ciências: 1) o argumento de que o progresso científico serve aos fins da humanidade, embora possa ser usado pelo cientista, não traduz o sentido intrínseco de sua atividade; 2) o argumento de que a ciência é uma atividade crítica e lúcida pode sim ser utilizado pelo cientista, mas os saberes produzidos pela ciência não resultam de relações neutras, desvinculadas das relações de forças sociais, mesmo porque as teorias científicas, não raro, resultam de "acordo" entre cientistas.

\section{CIÊNCIA E POLÍTICA}

De todo modo, como já dito, Stengers destaca que a abordagem sociológica colide com a concepção de ciência dos próprios cientistas, e é justamente essa abordagem sociológica que suscita protestos por parte destes, a quem ela se propõe a compreender. Os cientistas sentem-se "feridos" porque sabem que sua atividade não é apenas uma atividade social como outra qualquer, implica em riscos, exigências e paixões sem as quais ela não passaria de burocracia de números e de redes metrológicas. A ciência é isso também, mas não "só isso". "Revoltam-se" porque se sentem traídos por aqueles que têm mais poder de argumentação para pôr as ciências em cena, mas acabam usando sua retórica contra a realidade da ciência.

Mas, como já apontado, essa epistemóloga busca um caminho interpretativo diferente para as ciências. Sua ideia não é a de "subverter os sentimentos estabelecidos", não é a de colocar todos "de acordo", e sim visa:

\footnotetext{
(...) não ferir os sentimentos estabelecidos a fim de poder tentar abri-los àquilo que sua identidade estabelecida os obriga a recusar, combater, desconhecer. (...). Eu ousarei, neste livro, associar a razão científica à razão política. Sei que corro o risco de ofender todos aqueles para quem nada é mais importante existencialmente, intelectualmente, politicamente do que manter uma diferença. Porém, em nome desse sentimento estabelecido, eminentemente respeitável, seria preciso conservar categorias que, diariamente, dão prova de sua vulnerabilidade? Em nome da ciência", "em nome da objetividade científica", vemos serem criadas definições e redefinições de problemas que implicam a história humana. (ibid. p. 26, grifo nosso).
}

Busca, assim, articular aquilo que ela entende por ciência e o que entende por política, consciente de que podem ocorrer mal-entendidos e inquietações.

Sua postura é de que nem a política explica a ciência, como um projeto cuja aposta é o poder, nem a ciência transcende à política. Nenhuma pode ter a pretensão e o poder de explicar a outra. O que ela pretende é fazer funcionar o "princípio da irredução" - proposto por Bruno Latour, em Jamais fomos modernos (1994), que 


\section{Ensino, Saúde e Ambiente - V8 (2), pp. 111-141, Agosto, 2015}

prescreve um recuo frente a essa pretensão de saber e de julgar (STENGERS, op. cit., p. 27).

Por esse princípio, a ideia é tomar palavras como objetividade, realidade, racionalidade, verdade, progresso e colocá-las sob advertência em relação à tentação (que esse conjunto de palavras tem) de explicar reduzindo, ou de estabelecer uma diferença entre dois termos que os reduz a uma relação de oposição irredutível. Para Stengers, é preciso aprender a usar palavras (novas) que não dão o poder de revelar a verdade por trás das aparências (como concebem os cientistas) nem o de denunciar as aparências que ocultam a verdade (como pensam os sociólogos). Queria tornar possível um riso que não se abra às expensas dos cientistas, mas que possa, idealmente, ser compartilhado com eles (ibid., p. 29).

\section{EM NOME DA CIÊNCIA}

$\mathrm{Na}$ perspectiva de articular ciência e política, não de venerar nem de “denunciar", Stengers identifica no interior da ciência contemporânea a existência de práticas diferenciadas, embora todas reivindiquem para si um mesmo modelo - o de objetividade (que toma as práticas teórico-experimentais como paradigma), como: práticas experimentais criadoras (por exemplo, a definição do código genético no anos 60); práticas centradas no poder de um instrumento (pressupõem a criação de técnicas experimentais cada vez mais sofisticadas, e a produção de entes que são obrigados a "obedecer" os dispositivos que os quantificará e qualificará, como é o caso das partículas elementares, na Física de Partículas).

Em todos esses casos, segundo ela, observa-se um deslocamento de sentido que afeta o sentido do termo "objetividade" científica.

"Em nome da ciência", incontáveis animais foram viviseccionados, descerebrados, torturados, a fim de produzir "dados empíricos"; "Em nome da ciência", Stanley Milgram "repetiu" uma experiência ${ }^{5}$ já ocorrida na história humana e mostrou que se podia "em nome da ciência" fabricar torturadores como outros o fizeram "em nome do Estado".

Como "caso" ilustrativo de um setor em que os limites entre o científico e o não científico são rigorosos, ela toma a medicina. A medicina é uma ciência que

\footnotetext{
${ }^{5}$ Stanley Milgram, psicólogo americano, realizou em 1964 uma experiência sobre como os indivíduos tendem a "obedecer" às autoridades mesmo quando elas contradizem o bom senso individual. Através dessa experiência Milgram pretendeu explicar os crimes do nazismo, cometidos na Segunda Guerra Mundial. 
pretende se impor ao público, definido como "não-científico", exortando-o a aderir aos valores da ciência e o faz não por acaso, propõe Stengers. O conflito entre a medicina oficial (científica) e as medicinas alternativas, ou paralelas, tem uma história: $O$ conflito, indissociável da "experiência social" do médico, entre médicos diplomados e aqueles que são denunciados como charlatões, não foi criado "em nome da ciência", mas a referência à ciência deu-lhe novas feições (ibid., p. 33). Podemos nos perguntar: em que momento a referência à ciência modificou esse conflito? Em resposta, Stengers arrisca a hipótese de que não foi inovação médica que conferiu à medicina o direito de reivindicar o título de ciência, mas a maneira pela qual diagnosticou o poder do charlatão e explicitou as razões para desqualificar esse poder. Nessa linha, no momento em que os médicos "descobriram" que nem todas as curas são equivalentes teve início a medicina científica. O charlatão passou a ser definido como aquele que toma o efeito como prova: pó de pirlimpimpim ou alguns fluidos magnéticos podem ter um efeito na cura de corpos doentes, embora não possam ser tomados como causa. Essa definição da diferença entre medicina e charlatanismo é importante, assevera ela, porque deu origem aos testes de medicamentos baseados na comparação com os efeitos placebo. Mas teve a consequência de transformar a capacidade do corpo vivo de se curar pelas “más razões” em obstáculo.

Quando a medicina científica solicita ao público que compartilhe de seus valores, pede que resista à tentação de se curar pelas "más razões" como se um corpo doente pudesse diferenciar o "verdadeiro remédio" do "remédio falso"; ou pudesse distinguir entre restabelecimentos ativos e eficazes para qualquer um e restabelecimentos não reproduzíveis, que dependem das pessoas e das circunstâncias. Este último é tratado como obstáculo que precisa ser dominado.

A medicina, afirma ela, funciona por uma rede de restrições administrativas, gestionárias, industriais, profissionais, privilegia o investimento pesado - técnico e farmacêutico. O médico, que não quer se assemelhar ao charlatão, vive com algum malestar sua atividade; e o paciente, intimado a se curar pelas "boas razões", hesita. Em meio a esse emaranhado de problemas, constrangimentos, temores, onde está a “objetividade"? O argumento "em nome da ciência" está em toda a parte, mas não para de mudar de sentido (ibid., p. 35). 


\section{Ensino, Saúde e Ambiente - V8 (2), pp. 111-141, Agosto, 2015}

\section{RUPTURA OU DEMARCAÇÃO?}

Quando uma área adquire o direito de ser chamada de ciência, a seus praticantes são imputados direitos e deveres. Portanto, a definição de ciência nunca é neutra, sempre exclui ou inclui, questiona ou justifica, cria ou proíbe um modelo.

As definições de ciência por "ruptura" ou pela busca de um "critério de demarcação" distinguem-se de forma interessante, segundo Stengers, embora ambas tenham resultado em malogro. "Ruptura epistemológica" foi um termo introduzido por Gaston Barchelard e refere-se à recusa, ao "corte" à noção de "opinião" que "pensa mal" ou "não pensa" (Bachelard, 1996). A luta da ciência contra a opinião torna-se (...) o confronto entre os "interesses da vida" (aos quais a opinião está sujeita) e os "interesses do espírito” (vetores da ciência) (ibid., p. 36).

Essa definição tem, para Stengers, nuances "positivistas", pois age pela desqualificação da não ciência; está mais associada ao positivismo de Comte do que ao positivismo do Círculo de Viena (constituído por Moritz Schlick, Philip Frank, Rudolf Carnap e outros) que buscaram o ideal de depuração ou eliminação de proposições metafísicas, desprovidas de conteúdo empírico ou que não podiam ser deduzidas dos fatos por um processo lógico. De todo modo, aquilo que o positivismo desqualifica como opinião ou não ciência pode ser objeto de uma perda irreparável, vítima da destruição de significação e valor, assevera essa epistemóloga.

A "ruptura", como depuração ou maturação, cria uma assimetria na visão de Stengers: oferece recursos estratégicos aos campos que detêm o título de ciência e retira daqueles contra os quais a ciência se constituiu a possibilidade de contestar-lhes a legitimidade e pertinência. Uma característica dessa assimetria, especialmente nos textos de Bachelard, diz ela, é que a definição de não ciência é mais clara e segura do que a definição de ciência.

Ao contrário da desqualificação da opinião ou de tudo aquilo que a ciência já superou, a tradição demarcacionista, associada a Karl Popper, tem como ponto de partida uma crítica do positivismo (especialmente do positivismo lógico do Círculo de Viena), pois Popper não aceitava que as proposições "metafísicas" fossem consideradas destituídas de sentido. O falseacionismo de Popper propõe que nenhum acúmulo de fatos, seja qual for, é suficiente para confirmar uma proposição universal (teoria), mas que basta um único fato para refutá-la (falseá-la). Para Stengers, o que está em jogo é a conduta do cientista, uma estética de risco e audácia: Popper adotou sempre uma posição próxima daquela do "crítico de arte", pois, antes de mais nada, ele "amou” a ISSN 1983-7011 


\section{Ensino, Saúde e Ambiente - V8 (2), pp. 111-141, Agosto, 2015}

ciência tal como Einstein lhe parecia simbolizar. A constante de sua carreira sempre foi: seja qual for o critério, ele deve permitir compreender por que Einstein é um cientista e por que os marxistas e os psicanalistas não o são (ibid., p. 40). Aquele que escolhe, como Einstein, expor-se à crítica e refutação, toma a única via na busca da verdade.

Mas, adverte Stengers, Popper reconheceu que se não fosse o fato que constitui o "progresso", o fato de que os cientistas conseguem produzir teorias que resistem por algum tempo à falsificação, a prática da falsificação faria da história da ciência um cemitério de teorias pouco interessante. Nesse sentido, para ela, o verdadeiro interesse da busca por um critério de demarcação entre ciência e não ciência reside na tentativa de dar uma definição "positiva" da "verdadeira" ciência (ibid., p. 39).

A essa altura, na sua visão, surgem várias questões: ainda que nas ciências o caráter experimental seja incontestável, qual o sentido que o critério de demarcação poderia aspirar? Tratar-se-ia de um critério "realista", que ambicionaria caracterizar normas às quais o verdadeiro cientista se conforma? Seria ele suficiente para definir a atividade científica? Permitiria compreender na história das ciências o que estamos inclinados a reconhecer como "verdadeiramente científico"? Esse tipo de questão foi objeto de exame de um discípulo de Popper: Imre Lakatos. Diferente de Popper, para quem o cientista tem que "decidir" segundo critérios dogmáticos, ingênuos ou sofisticados (este último implica que conjeturas audaciosas sejam testadas), se uma teoria foi ou não refutada, Lakatos entende que o cientista não precisa tomar decisões instantâneas. Mas deve se perguntar se as modificações introduzidas ao longo do tempo no cinturão protetor do programa de pesquisa ampliaram seu poder preditivo, se deram acesso a fatos novos, se foram passíveis de testes independentes ou se, ao contrário, o programa foi continuamente sobrecarregado por acomodações ad hoc, cujo único significado é proteger o núcleo duro do programa de pesquisa. Se o cientista conclui que seu programa degenera, abandona-o e adota outro programa, mais progressivo.

Lakatos preservou a necessidade de uma decisão (embora não instantânea) e daí a necessidade de definição de critérios que permitam ao cientista a tomada de decisão sobre o abandono ou não de um programa de pesquisa.

Para Stengers, nisto os programas de pesquisa de Lakatos se deparam com a prova da história.

O próprio Lakatos terminou por reconhecer, pouco antes de sua morte, que o julgamento do homem de ciência só podia ter lugar a título retroativo. Somos 


\section{Ensino, Saúde e Ambiente - V8 (2), pp. 111-141, Agosto, 2015}

nós que sabemos agora que tal programa se degenerava. E este poder, conferido pela história, é de fato redundante: o filósofo confirma aos "vencidos" que estes estão indubitavelmente vencidos, mas não há nenhum recurso apropriado para avaliar e julgar as razões pelas quais esses vencidos se mantiveram presos ao seu programa, ele pode apenas dizer que a história não guardou essas razões (ibid., p. 46, grifo nosso).

A tradição demarcacionista, na visão de Stengers, ao invés de explicar o progresso como recompensa da "verdadeira" ciência, apenas comenta a maneira pela qual as "verdadeiras" ciências progridem. O ponto mais importante, que marca o fim da tradição demarcacionista, é a impossibilidade de formular explicitamente critérios que permitam a tomada de decisão (pelos cientistas), critérios que informados pelo passado valessem para o presente. Ou seja, não é a explicitação da racionalidade operando na ciência, mas é a história quem oferece ao filósofo da ciência o poder de julgar as práticas científicas (que exprimem o progresso), na medida em que se a história "consegue" reabilitar um autor, situando-o em sua época, pode "entrar" no seu laboratório e abri-lo a todas as influências sociais (assim, o historiador exprime-lhe a derrota como cientista).

As ciências dão com frequência a impressão de uma obra a-histórica (ibid., p. 51). Mas para inserir a ciência na história, como qualquer outra atividade humana, defende Stengers que, em princípio, não é legítimo pensar em dividir a história: a das produções científicas propriamente ditas de um lado; a das instituições, das relações dos cientistas com o meio, das restrições/ oportunidades sociais, econômicas, institucionais que afetam o campo científico, de outro.

Novamente ela se questiona: ainda que esse ideal seja legítimo, por que essa inserção não é tranquila? Como resposta, defende que é insuficiente invocar o caráter técnico das questões científicas, ou o fato de os historiadores terem se deixado impressionar pelos cientistas. Esses argumentos mascaram um problema mais profundo e vinculado às concepções de muitos cientistas modernos:

(...) ciências não são uma prática social como as outras. Em outros termos, o problema da história das ciências me irá permitir uma nova abordagem da singularidade das ciências: como meio de pôr à prova a prática histórica. (...). A história das ciências não tem por atores seres humanos "a serviço da verdade", se essa verdade deve se definir segundo critérios que fogem à história, e sim seres humanos "a serviço da história", que têm como problema transformar a história e transformá-la de maneira tal que seus colegas, mas também aqueles que, após eles, forem escrever a história, sejam obrigados a falar de sua invenção como "descoberta" que outros teriam podido fazer. (ibid., p. 52). 


\section{Ensino, Saúde e Ambiente - V8 (2), pp. 111-141, Agosto, 2015}

Essa história, portanto, cria uma diferenciação difícil de questionar. Existe, segundo Stengers, no coração da história das ciências uma difícil relação de força entre o historiador e seus atores. Cria-se uma assimetria:

A assimetria estabelecida entre vencedores e vencidos não é apenas um aspecto da situação que o historiador deve examinar, é igualmente um aspecto da herança que o constitui. (...) É difícil para o historiador, ao relatar o trabalho de Jean Perrin6 tentando impor o átomo aos seus contemporâneos mostrando que é possível contá-los, não repetir as palavras de Perrin, ou seja, não ratificar o sucesso do que se poderia dizer a "vocação" do cientista: obrigar o historiador a passar pelas suas próprias razões para contar seu trabalho. (ibid., p. 54).

Enfim, sustenta essa filósofa da ciência que a "força da história" construída pelos cientistas tem efeitos sobre o historiador e sobre os próprios epistemólogos. Ao abordar a questão da teoria dos "três mundos" Stengers conclui que para Popper, a força da história construída pelos cientistas está ligada ao fato de que os sujeitos "psicológicos" (mundo 2) não a dominam, mas sofrem a coerção dos problemas que eles fazem emergir. Assim, a história "interna" triunfa sobre a história "externa" vez que um partidário da história "externa" quer estabelecer uma correlação entre a posição de um cientista participante de uma controvérsia e os seus interesses culturais, sociais e políticos, o historiador "interno" pode dizer que a razão de ser da controvérsia é um problema objetivo e este, cria a possibilidade de que os interesses em conflito possam criar divergências científicas.

Segundo Stengers, esse desafio coloca a singularidade da história das ciências sob o signo da confrontação entre dois poderes: o da interpretação (que identifica crenças, convicções, ideias) e o do problema, cujo imperativo é fazer existir o cientista (ibid., p. 61).

\footnotetext{
${ }^{6}$ Jean Perrin, físico, realizou em 1909 a determinação, de forma precisa, do número de Avogadro a partir de medidas do movimento browniano de partículas coloidais, após a divulgação do artigo de Einstein de 1905 sobre o "movimento browniano". Constituiu-se em uma importante "prova" da existência de átomos e moléculas. O importante nessa discussão é compreender que ciência não se faz apenas com o que se observa. O observável frequentemente é explicado por teorias que "vão mais fundo na estrutura da realidade", postulando entidades e processos que não podem ser observados diretamente. É nesse caráter conjectural, hipotético e especulativo que reside o poder das grandes teorias científicas, que buscam compreender o que se observa através de níveis mais profundos da realidade.

7 A teoria dos "três mundos" foi proposta por Karl Popper como uma forma de ver a realidade, em que o mundo de divide em três categorias que interatuam entre si: Mundo 1 - é o mundo dos objetos, não apenas os visíveis, mas também os que escapam ao olho humano; Mundo 2 - é o mundo dos processos mentais, de onde irradiam as sensações de dor, prazer e pensamento; Mundo 3 - é o do conhecimento objetivo, onde os processos do mundo 2 são analisados. Fonte http://es.wikipedia.org/wiki/Doctrina_de_los_tres_mundos_de_Karl_Popper. Acesso em 28/01/2014.

${ }^{8}$ Para Solbes y Traver (2001) a abordagem histórica da ciência é caracterizada por aspectos internos, que dizem respeito ao conhecimento científico e tecnológico em si, e externos, que discutem as implicações sociais dos aspectos internos, por exemplo, a problematização de um conceito científico quando ele é discutido no âmbito escolar, no ensino de ciências sob um ponto de vista histórico.
} 


\title{
Ensino, Saúde e Ambiente - V8 (2), pp. 111-141, Agosto, 2015
}

\section{CONSTRUIR UMA DIFERENÇA}

Para Isabelle Stengers, a lição que se pode tirar dessas abordagens da ciência

(até aqui mencionadas) é que a singularidade do trabalho científico parece colocar seus intérpretes contra a parede.

Ou se busca, como os filósofos epistemólogos, como Thomas Kuhn, como Karl Popper, um meio de ratificar a diferença pretendida pelos cientistas, ou então, como Feyerabend e a maioria dos sociólogos das ciências contemporâneos que praticam o programa dito "forte" (e. g. David Bloor, 2009) que procura negar-lhe qualquer alcance "objetivo" (ibid., p. 73).

Contudo, o caminho adotado por Stengers, como já referido, é outro:

\begin{abstract}
A singularidade das ciências que, de meu lado, eu procuro construir será rejeitada pelos sociólogos em questão porque ela leva a sério o escândalo dos cientistas quando suas pretensões à objetividade são assimiladas a um "folclore particular", suscetível ao mesmo tipo de análise que os folclores de outras práticas humanas. (...).

A fim de consolidar a diferença ente a "abordagem sociológica", como a define o programa forte da sociologia das ciências, e a abordagem que procuro praticar, recorrerei a um contraste entre "sociologia" e "política" (ibid. p. 74, grifo nosso).
\end{abstract}

Assevera essa epistemóloga que não é preciso negar a especificidade ou singularidade das ciências para torná-la passível de discussão, que é possível tomar os cientistas como atores, assim como todos os outros na vida da cidade (preocupação "política") sem, necessariamente, descrever suas práticas como sendo semelhante a todas as outras (preocupação sociológica). E para isso, afirma:

Resolvi explorar este contraste porque ele me parece poder traduzir uma diferença menos empírica. É preciso dizer que a sociologia é a ciência dos sociólogos: a "sociedade" como tal reúne atores múltiplos, mas nenhum desses atores, salvo os sociólogos, tem interesse especial em definir o que "é" uma sociedade. A situação no campo da política é muito diferente. A política, no sentido prático, (...) é certamente o que os especialistas em ciências políticas procuram compreender; mas eles são sempre precedidos por práticas que se manifestam de forma explícita como práticas políticas. Em outros termos, a posição do comentarista "acompanhando" a história, que é a posição do especialista em ciências políticas, não é, a meu ver, uma deficiência, e sim o reflexo de que esse especialista se situa entre outros atores que colocam questões similares às suas. E que não cessam de inventar o modo como 'são discutidas e decididas' as referências à legitimidade e à autoridade, assim como a 'divisão' dos direitos e dos deveres, e a 'distinção' entre aqueles que têm o direito à palavra e os outros. (ibid., p. 75/76, grifo nosso).

Destacando o contraste entre sociologia e política, ela objetiva, primeiramente, explicar a inquietação dos cientistas frente às pretensões da sociologia da ciência de “fazer seu ofício", que é o de tentar interpretar as práticas sociais das ciências.

Mas os sociólogos da ciência buscam, em "nome da ciência", revelar aquilo de que participa do mundo do cientista, o tipo de projeto que o caracteriza sem levar em 


\section{Ensino, Saúde e Ambiente - V8 (2), pp. 111-141, Agosto, 2015}

conta os "mitos" da verdade, da objetividade que habita seu espírito ou se o cientista se acredita, ou não, como um ator autônomo. Dessa forma, a Sociologia, como definida por Stengers, outorga-se o "poder de julgar", de desvendar as regras da organização social nas ciências.

Os especialistas em ciências políticas, ao contrário, colocam-se diante de uma dimensão das sociedades humanas que não é passível de definição "objetiva". Trata-se de uma dimensão que faz uso de questões modernas e que corresponde em si mesma a uma criação de definições: quem é o cidadão? Quais são seus direitos e deveres? Onde termina o privado? Onde começa o público? (ibid., p. 77). Assim, as formulações e invenções da política não conferem ao especialista em ciências políticas (ou "politólogo") o poder de julgar, mas sim de acompanhar a construção das revindicações e das soluções que cada coletividade traz aos problemas constantemente colocados.

Assim, ao questionamento em torno de saber o que vem antes - os atores ou as estruturas sociais, como pretendem os sociólogos - se impõe um estado de conflito permanente.

Estaríamos muito longe das ciências, pergunta-se Stengers? Sua resposta é não. A oposição dos cientistas a toda sociologia das ciências pode então ser entendida em termos políticos (ibid., p. 82). O que está em jogo na questão da autonomia das ciências é a distinção entre aqueles que têm autoridade de intervir num debate científico (propor critérios, prioridades, questões) e aqueles que não têm esse direito. A questão posta é a distinção entre ciência e opinião, ou não ciência, e isto envolve o poder da linguagem, o poder de inventar "argumentos racionais" que submetem os fatos, que criam ilusões de necessidade.

Não se pode reduzir a "política da razão" (dos cientistas) a os jogos de poder aos quais comumente se associa a "política politiqueira". Reconhecer que as ciências têm uma dimensão política significa, para essa epistemóloga, compreender que o conflito entre as ciências e seus intérpretes (os sociólogos) é previsível no momento em que estes começam a julgar, ou a relativizar, a distinção entre ciência e não ciência. Uma coisa é interpretar essa distinção, mas questioná-la não é mais uma questão de interpretação e sim objeto de conflito (ibid. p. 83).

O interesse de Stengers em uma abordagem política dessa distinção é permitir criar um espaço de problematização em que a construção da diferença entre ciência e 
não ciência (ou da singularidade da ciência) possa ser acompanhada. O ponto não é negar as posições relativas entre os cientistas e os sociólogos, não é o de negar as diferenças pretendidas pelos cientistas, mas evitar todas as formas de descrevê-las que impliquem um conhecimento privilegiado dos cientistas em relação ao que significam essas diferenças que tanto os singularizam.

\section{A CIÊNCIA SOB O SIGNO DO ACONTECIMENTO}

A invenção da "arte política" pelos gregos foi um acontecimento, criou uma diferença. Mas o significado dessa diferença, as soluções trazidas ao problema aberto, as críticas, os comentários que essas soluções suscitarão, tudo isso faz parte dos desdobramentos do acontecimento e não dos atributos desse acontecimento.

Um acontecimento não determina a priori para quem fará uma diferença; não tem representante privilegiado; nem o poder de ditar a maneira como deverá ser narrado; nem o poder de selecionar quem o irá narrar e que consequências lhe poderão atribuir.

Nessa linha, colocar a questão da ciência sob o signo do acontecimento significa aceitá-la como processo contingente, contra os critérios ahistóricos da racionalidade. Para caracterizar a ideia de "processo contingente", segundo Stengers, não basta, como Kuhn, falar na existência contingente de sociedades e admitir a autonomia das comunidades científicas, ou falar no advento contingente de um paradigma. Nestes casos a contingência estaria no advento de um processo que a partir do momento em que encontrou a oportunidade de estrear, ganhou uma necessidade própria.

É preciso ir além, "inventar" um novo "motivo" de espanto para poder singularizar a ciência moderna como tal. E aqui a epistemóloga recorre novamente a um caso ilustrativo:

\footnotetext{
Meu espanto assim como minha motivação me vão remeter a Galileu. (...). E essa referência não é um artefato histórico: o próprio Galileu mostra-se perfeitamente consciente do fato de que, com ele, alguma coisa de novo estava em vias de se concretizar. Sua obra pública consagra um acontecimento, não somente um "novo sistema de mundo", mas também uma nova maneira de argumentar à qual ele confere o poder de fazer os adversários caírem no ridículo e de obrigar Roma a se curvar e a mudar a interpretação das Escrituras. (ibid., p. 90).
}

Para Stengers, apesar das controvérsias que causou, a utilização da luneta não foi suficiente para singularizar Galileu, nem a temível inteligência de seus argumentos, 
nem a força de sua obra que permaneceu estável e levou a melhor sobre a relatividade das opiniões e dos outros pontos e vista.

O motivo de assombro, para ela, está ligeiramente deslocado: o que singulariza as ciências não é a submissão a critérios que definiriam uma conduta científica. Galileu e sua luta contra Roma foram suscitados pelo acontecimento que é constituído pela possibilidade de se afirmar "isto é científico!" Poder afirmar "isto é científico" não é uma construção dos cientistas, fruto de acordo entre cientista. O olhar que cria a diferença é o "olhar do poder".

A forma como Galileu, sob o disfarce da Salviati, enuncia a definição de movimento uniformemente acelerado a seus interlocutores (Sagredo e Simplício), segundo Stengers, não é destituída de interesse.

Na obra Diálogo Galileu, disfarçado de Salviati, enuncia o movimento uniformemente acelerado a seus interlocutores: Simplício, que representa todos os seus adversários, e Sagredo, um homem de bom senso, com que os leitores se identificam facilmente. Galileu, no entanto, usa de estratégia quando Sagredo, deixando de lado sua imparcialidade, se une a Salviati para cobrir de insulto Simplício, e todos os que ele representa. O que Galileu faz na verdade é inventar uma verdade de um tipo novo, uma verdade que se confirma pela capacidade de fazer calar ou de ridicularizar seus opositores. Uma verdade que se anuncia de forma clandestina, segundo Stengers, porque está a serviço de outra questão: é para mostrar que a Terra poderia estar em movimento, sem que nós nos déssemos conta, que os enunciados sobre o movimento são apresentados. Na obra Discurso a respeito das duas novas ciências o tom foi outro. Galileu tinha sido condenado, estava envelhecido e escreveu clandestinamente endereçado muito mais ao futuro, aos seus sucessores, do que ao público. Simplício e Sagredo tornam-se simples coadjuvantes que opunham questões de que Galileu tinha necessidade para poder ressaltar a novidade e o significado do que estava propondo. Galileu fez parecer que seu enunciado, através das reações céticas de Sagredo, fosse uma definição abstrata, que remetesse a um autor que não tem o poder de franquear a distância entre a abstração que ele criou e o mundo real, onde os corpos caem naturalmente. Nesse episódio se percebe como o cientista pode fazer uso de sua pretensa autoridade encerrar o diálogo, para reafirmar sua ciência.

No Discurso, onde se trata de ciência, não de sistema de mundo, Galileu parece antecipar uma reação bem diferente do público bem diferente que ele busca interessar. Ele deve impor-se "malgrado" o ceticismo relativista (...). Os adversários de Galileu não foram somente os herdeiros retardatários de 


\title{
Ensino, Saúde e Ambiente - V8 (2), pp. 111-141, Agosto, 2015
}

\begin{abstract}
Aristóteles, o que teria por efeito colocar a Idade Média entre parênteses. A verdade anunciada por Galileu não tem apenas que se impor contra outra verdade que ela contradiga. Devia, antes de mais nada, impor-se contra a ideia de que todo conhecimento geral, "abstrato", é essencialmente uma ficção, ou seja, que não cabe ao poder da razão humana encontrar a razão da coisa, quer esta remeta à ordem das causalidades aristotélicas ou à matemática. (ibid., pp. 95-96).
\end{abstract}

O conhecimento como ficção remete ao que Stengers chama de "poder da ficção": o poder que a linguagem tem de elaborar argumentos racionais que submetem os fatos, o poder que produz uma aparente submissão do mundo a definições elaboradas no abstrato.

$\mathrm{Na}$ perspectiva dessa epistemóloga, o "poder da ficção" é que constitui o "campo de invenção" das ciências modernas e também aquilo que elas próprias contribuirão para estabilizar para melhor dele se distinguir. Em suma, a singularidade das ciências modernas está em um "novo uso da razão" que implica na incapacidade da razão de vencer sozinha o "poder da ficção".

Para aclarar, podemos pensar que religiões, escolas filosóficas ou correntes políticas são sistemas simbólicos contingentes, ou aleatórios, no sentido em que não se fundamentam em princípios lógicos ou universais capazes de justificar as relações de força que invariavelmente se estabelecem no interior desses sistemas. O que podemos perceber é que existem religiões, escolas filosóficas e partidos políticos concorrentes, que competem entre si. Mas é na política que essa concorrência pela adesão por parte do público é mais clara. Assim também é a ciência: um sistema simbólico contingente, com distintas correntes, teorias, campos de pesquisa que concorrem entre si e dentro do qual se estabelecem relações de força, como na política.

Esse é o sentido da contingência. É isso que revela a inseparabilidade entre ciência e ficção. O que a ciência faz, que é capaz de torna-la singular, é que ela exige que as ficções sejam muito especiais, capazes de calar aqueles que pretendessem contrapô-la afirmando "que isto não passa de ficção". Pode-se perguntar então: onde está a objetividade e a neutralidade que pretensamente caracterizam a ciência? Possivelmente esta questão não faça sentido. A ciência é humana, carrega as marcas humanas, segundo Stengers.

Para ela, esse é o sentido e o peso do "isto é científico". A tomada de decisão quanto "ao que é científico" não depende, portanto, de uma busca por normas, mas de uma política constitutiva das ciências: a legitimação de enunciados não vem de um direito epistemológico, também não vem da lógica de um juízo em busca de um 
fundamento, de um princípio universal. A lógica é outra. Trata-se de uma lógica do fundamento "aqui nós podemos".

Nesse sentido, o acontecimento galileano consagra um "novo uso da razão". O que Galileu faz é

(...) inventa, a respeito das coisas, um "como" que define o "porque" como seu resto. Seleciona aqueles que poderão participar da discussão do "como", de sua extensão e de suas modificações, e define os outros, filósofos e pessoas comuns, como aqueles que vêm depois, num quadro estruturado por uma divisão estabelecida entre o que "é científico", assunto dos cientistas, e o restante. Esses aspectos são, ambos, políticos. (ibid., pp. 101/102).

O primeiro aspecto prescreve a maneira, como convém, de tratar as coisas; o segundo, distribui entre os seres humanos as competências e as responsabilidades neste tratamento. Roma, afirma Galileu, não deve entrar no território das ciências, pois somente elas estão habilitadas a discutir qual deles, a Terra ou o Sol, gira em torno do outro (ibid.). Nessa linha, o "critério de demarcação" que Popper e seus discípulos buscaram, em vão, assume um mérito que não se deve ao uso "racional" da razão, mas à demarcação de territórios fortificados contra o "poder da ficção" por aqueles que se inscrevem na tradição científica - os cientistas.

Quando Galileu faz uso do "plano inclinado" (em o Discurso) ele representa, através de um esquema, as distâncias entre o ponto de impacto no solo e a borda de uma mesa de onde caíram bolas, que, antes de rolar sobre mesa, desceram de um plano inclinado sobre essa mesa; ele estabelece nos cálculos uma correlação entre as distâncias do solo e as alturas verticais de onde as bolas caíram antes de rolar sobre a mesa; ele articula três tipos de movimentos: movimento de queda, que é caracterizado pela altura de queda; movimento horizontal sobre a mesa e o movimento de queda livre, que é caracterizado pela distância horizontal que a bola consegue percorrer (para uma mesa de altura dada). Esse esquema representa um dispositivo experimental (sentido moderno do termo) de que Galileu é autor. Esse dispositivo, além de articular três tipos de movimentos, permite definir conceitos de velocidade e propõe uma relação operacional de equivalência entre as velocidades: a velocidade instantânea que caracteriza o móvel no final da queda é igual àquela que ele ganhou no passado e é igual àquela que no futuro irá caracterizar o seu movimento uniforme. Para Stengers, o que o dispositivo de Galileu implica é mostrar que a "lei do movimento" não está vinculada à observação mas a uma ordem de "fato" criada. Esse artefato de laboratório, 


\section{Ensino, Saúde e Ambiente - V8 (2), pp. 111-141, Agosto, 2015}

criado por Galileu em 1608, segundo essa epistemóloga, faz existir em laboratório o mundo que Galileu abre aos seus leitores em termos de experiência de pensamento.

Pode-se dizer que se trata de um mundo abstrato, idealizado, geometrizado. Mas o que o torna singular? O mundo fictício proposto por Galileu não é somente o mundo que Galileu sabe como questionar, é um mundo que 'ninguém pode questionar de um modo outro que o dele' (p. 106). O mundo que Galileu propõe é "abstrato", no sentido de que muitas coisas foram eliminadas - idealizadas - mas é uma "abstração" que permite a criação de um ente concreto capaz que calar os rivais daquele que o concebe. A "abstração" não é "uma maneira abstrata de ver as coisas". A "abstração" não tem nada de psicológico ou metodológico. Trata-se, antes, de uma invenção de uma prática experimental que, além de distingui-la de outras ficções, cria um fato que singulariza uma classe de fenômenos entre outros. Mas o que pode ser "objeto de representação", e o que pode "escapar" à representação, é uma diferença tal, que não está fundada "a priori" na teoria. É nesse sentido que para Stengers a "representação" científica tem um sentido mais próximo da política, do que aquele que ela assume na teoria do conhecimento.

Para ela, as ciências modernas caracterizam-se pela "invenção de uma prática original" de atribuição de qualidade de autor que tira dois tipos de vantagem: o autor como indivíduo dotado de intenções, de projetos, de ambições; o autor que encarna autoridade. Esse é o sentido do acontecimento concebido pela invenção experimental: $a$ invenção do poder de conferir às coisas o poder de conferir ao experimentador o poder de falar em seu nome (ibid., p. 108).

\section{O PODER EM HISTÓRIAS}

Stengers destaca uma diferença relevante entre "histórias científicas" e "histórias que se constroem em nome da ciência" (como na medicina, que para se legitimar como ciência teórico-experimental precisou desqualificar a "cura por más razões", precisou varrer as pretensões dos "charlatões"). Assume que acompanhar a maneira pela qual a referência à ciência muda de sentido, vai do risco ao método, da criação de uma relação singular com a coisa ao juízo que constitui a singularidade da coisa como obstáculo... (ibid., p. 136). E ela se questiona: como o conjunto de relações práticas e das significações que unem os seres humanos entre si e com as coisas tornouse disponível para as "estratégias conduzidas em nome da ciência"? 


\section{Ensino, Saúde e Ambiente - V8 (2), pp. 111-141, Agosto, 2015}

Para responder, em parte pelo menos, ela busca distinguir entre "enunciado experimental" e "teoria". Um enunciado experimental pode transformar, subverter a paisagem dos acontecimentos, conectar regiões, desconectar outras, mas define possíveis critérios disponíveis para todos, ou seja, restrições que todos deverão levar em conta, mas também que todos poderão aproveitar se meios para tal forem inventados. A teoria, por sua vez, necessita que a hierarquização dos saberes que ela propõe seja ratificada socialmente. Para esclarecer: uma ciência que coloca questões essenciais é uma ciência de ponta, tomada como uma "ciência pura"; outra, que pode ser útil porque pode preparar o terreno para a ciência pura, seria a "ciência aplicada" dado que admite questões subordinadas à ciência pura (a engenharia, por exemplo, baseada na mecânica galileana/newtoniana) que admite que aquilo que interessa seja definido pela ciência pura, seria esta uma ciência parasita, secundária. Ocorre que esta situa seus problemas “à distancia do ideal", que seria um mundo sem atrito - um mundo em que o engenheiro não teria como trabalhar, e por isso pode ser denunciada como parasita ideológica, não objetiva; estaria testemunhando outra espécie de verdade. Assim é que, para Stengers, toda a teoria afirma um poder social, um poder de julgar o valor das práticas humanas; nenhuma teoria se impõe sem que, em algum momento, o poder social, econômico ou político tenha agido (ibid., p. 137).

Para essa epistemóloga, as teorias triunfantes galgaram esse status porque engendraram histórias fecundas, às vezes contra expectativas morais. Mas o objetivo, para Stengers, ao propor tais questões não é o de nos transformarmos em justiceiros, mas de nos interessarmos pelas "estratégias da ciência". A ciência apela a pretensões gerais (progresso, objetividade, ir além das aparências) mas esses mesmos temas remetem a o poder social (público, colegas não implicados, sócios capitalistas, etc.) para reforçar o caráter hegemônico daquilo que ela pretende hierarquizar, unificar.

Examinadas sob este viés (grifo nosso), duas teorias podem ser perfeitamente diferentes mesmo que utilizem o mesmo tipo de formalismo: a teoria quântica do átomo reúne físicos e químicos todos interessados em suas possibilidades de representação; em contrapartida, a teoria quântica da medida dirige-se, em princípio, a toda humanidade no sentido em que pressupõe que tudo o que existe (exemplo o "gato de Schröedinger") pode ser representado à maneira de um átomo de hidrogênio isolado e coloca de modo técnico a questão da emergência de certas propriedades (um gato que estaria morto ou vivo e não morto $e$ vivo) fazendo parecer que a própria existência do mundo onde 


\section{Ensino, Saúde e Ambiente - V8 (2), pp. 111-141, Agosto, 2015}

vivemos depende do veredito da mecânica quântica, que unifica o conjunto de conhecimentos sobre o mundo. Quando se trata de fazer o público interessar-se pela mecânica quântica é evidentemente pelo gato de Schroedinger, de preferência ao átomo de hidrogênio, que os vulgarizadores passam (ibid., p. 139). O gato de Schroedinger torna-se um símbolo da capacidade da mecânica quântica de colocar em cheque as evidências do senso comum, segundo Stengers.

Sua ideia é acompanhar os "modos" da ciência sem ingenuidade, e sem denúncia. Aprender a resistir com humor. Perceber que há muitas maneiras de contar história das ciências, de nela fundar as políticas do futuro, de mobilizar o seu modelo, de inventar uma retórica mobilizadora.

Os cientistas, para Stengers, têm à mão, com facilidade, outras palavras para narrar o progresso da ciência. Há um contraste entre os efeitos da prática experimental e a retórica. Aqui ela cita um exemplo: Jean Pires, em 1912, impôs aos céticos uma visão de mundo em que era possível interpretar os fenômenos macroscópicos em termos dos movimentos dos átomos imperceptíveis. O que ele fez foi impor uma multiplicidade de situações em que os átomos ao se ionizar, ao entrar em reação, ao se entrechocar, ao determinar o movimento errático de uma partícula browniana acabam por testemunhar sua existência, que deixa de ser uma ficção. Os átomos, as moléculas, assim, são condições dadas da nossa história, mas eles só "fazem história" na medida em que a retórica modifica o significado da explicação. Para

Stengers, essa retórica reducionista é tão poderosa que passam em brancas nuvens $o$ fato de que a diversidade "explicada" normalmente não preexistia à explicação, que é menos conquista do que produto de uma invenção prática que vem se somar a outras práticas (ibid., p. 141). Ela chama a isto de "encenação mobilizadora" que constitui uma forma de organização política peculiar (que tem coerência de conjunto, disciplina, comando central que alinha interesses e uma enorme capacidade de negociar com poderes modernos - Estados ou indústrias, potencial ou ativamente interessados pelos saberes e pelas práticas científicas).

\section{O OFÍCIO DO CHEFE}

Isabelle Stengers cita uma passagem de Bruno Latour (1997) em que ele descreve uma semana da vida do chefe de um laboratório de neuroendocrinologia logo depois de ser identificado um hormônio secretado pelo cérebro: a pandorina. Nessa 


\section{Ensino, Saúde e Ambiente - V8 (2), pp. 111-141, Agosto, 2015}

passagem, assevera Stengers, Latour consegue captar um delicado movimento: de um lado a constituição de um campo disciplinar (a neuroendocrinologia) e de outro, a "construção social" de um mundo que permite aos frutos dessa disciplina "fazer história" com os interesses sociais, econômicos, políticos, industriais, etc. (ibid., p. 145).

Trata-se de uma relação ao mesmo tempo intensa e encoberta. Dessa relação pode a "pandorina" ser simplesmente uma molécula biológica, produto de uma pesquisa honesta, ou o ponto de partida de uma "revolução" que pode render ao chefe o prêmio Nobel. O trabalho, as viagens, as promessas, as negociações do chefe podem resultar em interesse da indústria, em recursos para aquisição de novos aparelhos; do interesse da indústria depende a multiplicação dos atributos da pandorina, o reconhecimento dos referees de jornais científicos; o abrandamento de "obstáculos da papelada" para os testes clínicos. Enfim, o chefe faz o que deve fazer caso pretenda conferir à pandorina todo o alcance possível (ibid., p. 147). Mas a pandorina não depende apenas das estratégias do chefe: ela deve ser contrastada com severos testes na academia e na indústria até, possivelmente, tornar-se um medicamento.

Mas, adverte Stengers, nada confere à pandorina "em si" - independentemente do chefe - o poder de incitar esses testes, de impor interesses aos pesquisadores, às indústrias, aos jornais científicos. Essa relação está no chefe. E mesmo os colaboradores mais desinteressados do laboratório que o chefe representa dependem do trabalho interessado do chefe. É com os recursos e apoios deste que eles conseguem levar adiante a pesquisa, fazer seu trabalho desinteressado e cada vez mais dispendioso. Nesse sentido, o chefe é coagido a se interessar, a viajar pelo mundo para que o mundo faça a molécula existir. Esse trabalho dissipa as trevas irracionais porque consegue construir um triplo campo: a molécula, a futura ciência do "cérebro úmido" e o progresso experimental.

Contudo, a singularidade do chefe pouco tem a ver com "uma identidade da ciência". Como saber em que ponto a "ciência" pára e começa a propaganda? Em que ponto o chefe deixa de exercer seu papel de cientista interessado e recrutador de aliados e passa a ser (ele próprio) dominado? (no seu papel de passar a pandorina bioquímica à pandorina cultural, de uma pandorina que reúne disciplinas em uma nova disciplina a uma pandorina futuro medicamento - que atrai interesses industriais, que atrai os estudantes que se destinam à pesquisa de ponta etc.). Para Stengers, alguns dos 


\section{Ensino, Saúde e Ambiente - V8 (2), pp. 111-141, Agosto, 2015}

aliados do laboratório - que simbolizam o progresso da ciência - têm exigências a serem satisfeitas, outros são definidos por uma lógica competitiva à qual deverão se submeter e outros são definidos por crenças, temores e esperanças a serem alimentadas. Nesse sentido, os diferentes atributos da pandorina são construídos através de coerções. Trata-se, para essa epistemóloga, de uma construção assimétrica: de um lado a pandorina do laboratório é suficientemente interessante para reorganizar a disciplina, de outro, os aliados mais exigentes demandam contínuas remodelações que o chefe é incapaz de prever. Cabe, contudo, destacar aqui que a pandorina é um caso e o estudo de caso não objetiva a generalização.

\section{QUESTÕES POLÍTICAS}

A produção científica depende, em certos casos, como busca mostrar Stengers, da seleção de aliados, no sentido de fazer existir o máximo de interessados, competentes ou não-competentes. Como evitar de remeter a paisagem de nossas práticas, de nossas ações e de nossas paixões a uma instância global que teria poder de explicá-la e que bastaria denunciar? (ibid., p. 150).

Por exemplo, fazer sair do laboratório a bomba de ar de Boyle, que a partir do próprio Boyle não parou de se transformar, de se aperfeiçoar até adquirir o direito de ser chamada de "bomba a vácuo", pressupõe, além admitir a existência do vácuo, admitir uma multidão de usuários satisfeitos - embora para a maioria ela seja uma "caixa preta". Todos aqueles que abrem um pacote de café e ouvem o "pshhht" sabem que estão lidando com uma embalagem a vácuo.

Bruno Latour recusa-se a falar de racionalidade, eficácia, calculabilidade, cientificidade (termos que explicam a construção a partir dos atributos do que foi construído) e ele tem razão, diz Stengers, mas ele se recusa também a falar em poder. $O$ “chefe”, é claro, não sabe o que ele põe em movimento, como também os pesquisadores que, para alimentar suas pesquisas, nutrem o público de esperança num futuro em que as “doenças genéticas” serão curáveis. (ibid., p. 151).

Para essa epistemóloga, o poder é responsável por tudo o que não funciona, e precisa ser denunciado. Ele não está "para além" da rede, ele qualifica a rede e estabelece seus limites. É o poder quem estabelece os pontos onde a noção de interesse muda de sentido, onde cessamos de nos dirigir aos protagonistas que queremos interessar e onde começam as estratégias que pressupõem que o interesse possa "ser 
comandado". Esses pontos, segundo essa epistemóloga, são numerosos e precisam ser mapeados, pois demarcam duas posições: uma instância à qual se atribui o poder e um mundo disponível - salvo resistências - ao desdobramento dos seus efeitos.

A paisagem dos conhecimentos científicos também apresenta hierarquias. $\mathrm{O}$ modelo da conduta teórico-experimental e suas estratégias de mobilização não cessa de selecionar o que constitui uma "boa" abordagem, o que pode ser considerada uma "dificuldade secundária" ainda não superada. A questão é que os desníveis fazem rizomas ${ }^{9}$. São, para Stengers, muito mais fáceis de manipular os experts que representam um campo da ciência onde reina o desprezo por aquilo que não pode ser reproduzido em laboratório. São mais aptos a transmitir uma inovação científica como "firmando autoridade" aqueles que a aprenderam pelo modo da evidência.

Não é fatal que as ciências sejam aliadas ao poder. Porém elas são vulneráveis àqueles que podem contribuir para criar diferenças, firmar interesses, desqualificar questões incômodas, facilitar a saída dos laboratórios (p. 154). Nesse sentido, Isabelle Stengers atribui à ciência uma singularidade, de inventar meios de vencer o poder da ficção (isto é, de fazer a diferença entre ficções), isto a torna tecnicamente solidária com um "compromisso com o verdadeiro" que define o que não é científico como fictício, que desqualifica aquilo que é considerado "obstáculo".

Adverte ela que assim como a filosofia não era amiga da cidade grega onde nasceu, a ciência não é amiga do capitalismo. A referência à "ciência moderna" nasce pela descoberta de que o poder da ficção, a invenção do laboratório, pode ser voltado contra o arbitrário da ficção, mas pode ser do interesse da ciência remeter ao arbitrário da ficção tudo o que não é ciência.

\begin{abstract}
A priori, nada impede de imaginar cientistas conscientes do fato de que, ao mudar de meio, ao não se dirigir mais a colegas, ao participar da invenção das inovações irredutivelmente técnicas e sociais, devem igualmente mudar de estilo "ético-estétito-etológico". Pois tudo muda quando se sai do laboratório, lugar onde os fenômenos são inventados como testemunhas fidedignas, capazes de fazer a diferença entre verdade de ficção. No laboratório de Galileu, por exemplo, reúnem-se aqueles que concordam em se interessar pelo movimento que o plano inclinado inventa e encena. Fora do laboratório encontramos o atrito, o vento, a irregularidade dos solos e a densidade dos meios materiais, tudo aquilo cuja eliminação permitiu a Galileu firmar autoridade. Encontra-se também um mundo em que operam outros atores, perseguindo outros projetos (...). A propósito desses atores, o
\end{abstract}

\footnotetext{
${ }^{9}$ Rizomas: em Botânica são um tipo de caule que cresce horizontalmente, em geral, subterrâneo mas podendo ter porções aéreas. Fonte: http://pt.wikipedia.org/wiki/Caule. 


\section{Ensino, Saúde e Ambiente - V8 (2), pp. 111-141, Agosto, 2015}

cientista consciente de que muda de meio, colocaria a questão: "Por que sou tão interessante para eles? Onde estão os outros, os capazes de levar em conta aquilo que, para me autorizar a falar, meu laboratório se obriga a eliminar?” (ibid., p. 155).

A manutenção da autonomia das ciências não implica que os cientistas fiquem indiferentes aos interesses do mundo "não científico", nem que fiquem proibidos de explorar os recursos financeiros, tecnológicos ou outros que ele pode lhes oferecer ou que eles próprios podem concretizar. $O$ que torna singular a ciência é que ninguém poderia dizer: esta hipótese, esta maneira de tratar um problema, foi reconhecida como "científica" porque caminhava no sentido dos interesses econômicos, industriais ou políticos. Se o cientista fizesse valer esses interesses em lugar dos "argumentos científicos" ele seria acusado, ao passo que se consegue fazer convergir esses interesses com aqueles de sua disciplina e, além disso, aproveita os recursos que essa convergência oferece, será reverenciado, segundo Stengers.

\section{QUE SINGULARIDADE ATRIBUIR ÀS CIÊNCIAS?}

Stengers reconhece que sua discussão é insuficiente para arbitrar a "singularidade" das ciências modernas, pois centra seus argumentos nas práticas teórico-experimentais. Propõe que existem muitas ficções, mas para ela, as ciências modernas constituem sim certa "singularidade" (não pela racionalidade e objetividade defendida pelos cientistas, que ela critica), mas por sua capacidade de inventar novos meios de fazer a diferença e produzir testemunhas fidedignas, especialmente entes criados em laboratório pelas práticas teórico-experimentais. A paixão dos cientistas "por fazer existir" incita-os a buscar aliados que lhes ofereçam os meios a essa paixão, a criar "situações" e testes capazes de calar seus rivais, a colocar em jogo todo seu poder de representar.

Essa dinâmica teórico-experimental distingue a ciência da "simples opinião" variável e arbitrária, mas ao mesmo tempo pode colocá-la em situações de impotência (por exemplo: favorecer o discurso dos criacionistas, que não aceitam substituir a narrativa bíblica pelo discurso darwinista, justamente porque este não pode usufruir da característica que expressa o poder teórico-experimental, os experimentos).

$\mathrm{Na}$ perspectiva por mim proposta, a atividade científica [expressa uma singularidade e] integra uma forma de polêmica e de rivalidade, promove um “compromisso" que liga interesse, verdade e história de um modo que não é nem o dos ISSN 1983-7011 


\section{Ensino, Saúde e Ambiente - V8 (2), pp. 111-141, Agosto, 2015}

saberes tradicionais, nem aquele tradicionalmente vinculado à imagem feminina [referindo-se às “críticas radicais" já mencionadas neste texto] (...) (ibid., pp. 159-160) e associa atividade apaixonada (como Galileu, Newton e tantos outros) de um lado, e discursos sobre o método e a objetividade de outro, ao passo que os demais saberes (tradicionais) ficam condenados a essa "grande divisão". O desafio de distinguir ciência e poder, sem separar ciência da polêmica, é tão polêmico como o da linguagem que distingue sujeito e objeto. Stengers defende a tese que a singularidade das ciências modernas implica a manutenção da distinção [sujeito e objeto], porque é desta distinção que surge o risco (p. 161) como um operador de desalinhamento, que implica que a ciência moderna não pára de ser reinventada, não pára de inventar novas medidas, novas relações, novos testes, novos meios de comprometimento.

O surgimento e o uso de modelos é um protagonista capaz de colocar em questão a possibilidade de distinção entre teoria e o modelo. O modelo se coloca ou se define pela capacidade de representar um fenômeno sem impor uma relação de força podem coexistir diversos modelos, definidos por distintas variáveis, para representar um mesmo fenômeno, vinculados à escolha do autor. Nesse sentido os modelos são espontaneamente ficções. Ao mesmo tempo constituem uma forma de colocar à prova as ficções sem ter por objetivo a eliminação dos rivais.

$\mathrm{Na}$ época de Galileu o uso regrado da ficção descobriu na matemática um instrumento privilegiado. Nos dias de hoje, o uso da matemática como instrumento de ficção assume um novo porvir através do desenvolvimento das técnicas de informática. A força do computador como instrumento de simulação coloca aos cientistas um novo compromisso, não mais ao de uma verdade que faz calar as outras ficções, mas de qualquer que seja o fenômeno - ter a possibilidade de construir a ficção matemática que o reproduz. Nesse sentido as simulações computacionais não apenas propõem o uso ficcional da matemática, mas subvertem igualmente a hierarquia entre o fenômeno depurado, correlato da inteligibilidade ideal inventada pela representação experimental, e as complicações anedóticas (p.165). Em outras palavras a simulação computacional é uma arte que coloca em cena uma heterogeneidade de elementos e constrói uma história e coloca em contato, sob um novo modo, o experimental, as leis, a descrição, a explicação, a ficção. Este é mais um elemento que as ciências modernas sabem aproveitar para se reinventar. 


\section{Ensino, Saúde e Ambiente - V8 (2), pp. 111-141, Agosto, 2015}

\section{CONSIDERAÇÕES FINAIS}

Para Demo (2011) admitir critérios políticos de cientificidade como sendo intrínsecos à dinâmica das ciências é uma atitude que causa espanto (assombro nas palavras de Stengers) porque agride a expectativa de sua formalização pretensamente neutra. É importante ter presente que não é o aspecto formal das ciências que Stengers questiona, mas é algo para além do formal. Trata-se do significado cultural, histórico, da dinâmica e uso social da ciência que ela discute ao tentar aproximar ciência e política. Conceber o conhecimento como dinâmica política pressupõe assumir uma nova concepção não restrita a faces formais e historicamente estabilizadas, mas como dinâmica desconstrutiva e reconstrutiva e que está na base da formação da autonomia. É isso que, na prática, confere tamanha relevância ao conhecimento científico, a ponto de ser considerado hoje o "capital” maior" (DEMO, 2011, p. 25).

O ser humano é um ser político. Sua politicidade intrínseca carrega no seu cerne a ambição de não ser joguete do outro, ou do destino, mas ser capaz de construir sua história, individual ou coletiva (ibid., p. 79). Estender essa ideia para a ciência significa assumir que, como em outras esferas humanas, as disputas de poder são naturais. Para Stengers, essa concepção permite vislumbrar que a pretensão da ciência de ser herdeira da "verdade" (capaz de encerrar qualquer discussão com base em neutralidade e objetividade) não é senão trejeito político para se singularizar, e não ser contestada.

Não é difícil de perceber que confrontos, nunca plenamente resolvidos, são comuns na ciência (e.g. a tensão evolucionismo versus criacionismo - que frequentemente é retomada - ou a batalha das teorias científicas avançadas em torno da origem do universo). Assim como não é difícil de apontar critérios políticos como constituintes das ciências (ibid.): o "mérito acadêmico" dos cientistas não é tão óbvio de ser caracterizado porque entram em cena muitas questões, como a forma de avaliar materiais para publicação, projetos de pesquisa, pedidos de financiamento, participações em seminários, envolve intersubjetividade, acordo relativo, lideranças nos departamentos e nas universidades, enfim, é um processo em que nem sempre vale a "autoridade do argumento" (que deveria valer sempre) e dá lugar ao "argumento da autoridade".

Se o objeto de cada nova epistemologia pode ser tomado como sua capacidade de discutir de uma nova maneira a produção conhecimento científico, então, sem dúvida, a visão Isabelle Stengers é uma voz que não pode ser ignorada. A questão não é 
a de nos colocarmos contra ou a favor de sua postura, às vezes muito dura com relação a ciências não médicas, não farmacêuticas, não biológicas - como a Física, por exemplo. O que importa é nos permitirmos refletir e dialogar com distintas posturas. Colocar professores e futuros professores em contato com novas visões, questionamentos totalmente novos pode ser uma abertura à transformação.

Os desafios com que os professores se deparam cotidianamente, o mundo virtual (alunos com acesso a wikis, blogs, redes sociais, textos provisórios, comentáveis, editáveis, de validade às vezes "relativa") favorece uma perspectiva de "discutir o conhecimento". Entretanto, o mundo virtual mostra faces, no mínimo, ambíguas: de um lado favorece a democratização do conhecimento, de outro, compromete a qualidade das informações, distorce-as, por vezes.

O que não se pode é ignorar que vivemos um período de mudanças sociais profundas, muitas resultam da revolução tecnológica, proporcionada pela ciência. Essas mudanças interferem tanto nos modos como recebemos e lidamos com a informação, quanto nas escolhas, nas opções de consumo, nas formas de relacionamento e por que não na forma como concebemos a ciência e como ensiná-la? Refletir essas questões é, assim, mais do que pertinente.

\section{REFERÊECIAS:}

BACHELARD, G. Formação do espírito científico. Rio de Janeiro: Contraponto, 1996.

BLOOR, D. Conhecimento e imaginário social. São Paulo: Editora UNESP. 2009.

CRESWELL, J. W. Investigação qualitativa e projeto de pesquisa. Porto Alegre: Penso, 2014.

DEMO, P. Praticar ciência: metodologias do conhecimento científico. São Paulo: Editora Saraiva, 2011.

KUHN, T. A estrutura das revoluções científicas. São Paulo: Editora Perspectiva. $8^{\text {a }}$ ed., 2003.

LATOUR, B. Jamais fomos modernos. São Paulo: Editora 34, 1994.

LATOUR, B.; WOOIGAR, S. A Vida de Laboratório: a produção dos fatos científicos. Rio de Janeiro: Relume Dumara, 1997.

PIVA, A. A invenção das ciências modernas. Resenhas. Revista da SBHC, vol. 2, n. 2, p. 163-165, 2004. 
Ensino, Saúde e Ambiente - V8 (2), pp. 111-141, Agosto, 2015

PRIGOGINE, I.; STENGERS, I. A nova aliança: metamorfose da ciência. Brasília: Univ. de Brasília, 247 p., 1991.

SOLBES, J.; TRAVER, M. Resultados obtenidos introduciendo Historia de la Ciencia en las clases de Física y Química: mejora de la imagen de la ciencia y desarrollo de actitudes positivas. Enseñanza de las Ciencias, vol. 19, n. 1, p. 151-162, 2001.

STENGERS, I. A invenção das ciências modernas. São Paulo: Editora 34, 2002.

STENGERS, I. L'invention des sciences modernes. Paris: Champs-Flammarion, 1995. 